\title{
Pengembangan Modul Pembelajaran Berbasis Problem Solving pada Materi Gerak dan Gaya Kelas VIII SMP
}

\author{
El Arni Deti, Husna, Megasyani Anaperta \\ Program Studi Pendidikan Fisika STKIP PGRI Sumatera Barat \\ 03elarnideti@gmail.com
}

\begin{abstract}
This study aims to develop a physics learning module based on problem solving that is valid and practical on the material of motion and style for grade VIII students of SMP Negeri 16 Kerinci. The research method used is the development of a 4-D model (Define, Design, Develop, and Dessiminate). The define stage consists of syllabus analysis, textbook analysis, literature review analysis, student and educator interviews. At the design stage, the product design is carried out, namely the module, then at the develop stage, the module validation test is carried out by 2 validators. Practicality test by 1 physics educator and 24 class VIII B students of SMP Negeri 16 Kerinci. Based on the results of the study, it was obtained that the average value of the module validity test by three validators was $97.03 \%$ with the very valid category. While the practicality test with respondents consisting of one educator and class VIII B students totaling 24 people was obtained $91.63 \%$ with the very practical category. So it can be concluded that the physics learning module based on Problem Solving on the motion and style material of the VIII grade students of SMP Negeri 16 Kerinci which is produced has been categorized as valid and practical.
\end{abstract}

Keywords: Problem Soving, Valid, Practical

(c) This is an open access article distributed under the Creative Commons 4.0 Attribution License, which permits unrestricted use, distribution, and reproduction in any medium, provided the original work is properly cited. $@ 2018$ by author and Universitas Negeri Padang.

\section{PENDAHULUAN}

Pada kemajuan teknologi di era globalisasi sudah banyak yang berkembang, diantaranya dunia pendidikan. Dunia pendidikan sangat perperan penting dalam proses mendapatkan ilmu pengetahuan padi individu, dimana dunia pendidikan sangat dibutuhkan oleh seluruh individu yang menimbulkan rasa ingin tahu yang besar serta untuk mengembangkan potensi dirinya terhadap lingkungan hidupnya. Hal ini berkesinambungan dengan kemajuan dalam bidang IPTEK yang memerlukan sumber daya manusia yang mampu bersaing dalam berbagai bidang tertentu. oleh karena itu, bisa kita simpulkan dengan meningkatkan mutu di pendidikan dapat membangkitkan kemajuan IPTEK di Indonesia.

Pemerintah mempunyai peran penting dalam menyempurnakan mutu pendidikan, seperti pergantian kurikulum, pelatihan kepada pendidik serta sarana prasarana. Menurut Undang-Undang No. 20 Tahun 2003 pasal 1 menyatakan bahwa:

"Pendidikan adalah usaha sadar dan terencana untuk mewujudkan suasana belajar dan proses pembelajaran agar peserta didik secara aktif mengembangkan potensi dirinya untuk memiliki kekuatan spiritual keagamaan, pengendalian diri, kepribadian, kecerdasan, akhlak mulia, serta keterampilan yang diperlukan dirinya, masyarakat, bangsa dan negara".

Pendidikan merupakan suatu usaha yang dijalani oleh individu atau beberapa orang dengan tujuan untuk memperoleh ilmu pengetahuan serta mengembangkan potensi dirinya. Di dunia pendidikan terdapat suatu Standar Nasional Pendidikan yang harus dicapai dalam pelaksanaannya yang terdiri dari 8 standar, adapun standar yang dimaksud yaitu standar isi, standar proses, tenaga kependidikan, kompetensi lulusan, pengelolaan, sarana dan prasarana, pembiayaan, dan penilaian pendidikan yang harus ditingkatkan secara berencana dan berskala. Dari ke delapan standar di atas, tiga standar seperti standar isi, standar proses, dan kompetensi lulusan merupakan acuan dari pendidikan.

Suardi (2018:7) menjelaskan bahwa "pembelajaran adalah proses interaksi peserta didik dengan pendidik dan sumber belajar pada suatu lingkungan belajar. Prastowo (2011:28) menjelaskan bahwa "Pembelajaran merupakan bantuan yang diberikan pendidik agar dapat terjadi proses memperoleh ilmu dan pengetahuan, penguasaan kemahiran dan tabiat, serta pembentukan sikap dan kepercayaan pada peserta didik". Dari uraian di atas, dapat disimpulkan bahwa pembelajaran adalah suatu proses kegiatan belajar mengajar yang dilakukan 
oleh pendidik terhadap peserta di kelas secara efektif dan efisien dengan hasil optimal.

Adapun hasil dari observasi yang dilakukan di SMP Negeri 16 Kerinci mengidentifikasikan bahwa sebagai peserta didik beranggapan bahwa fisika itu sulit dan banyak rumus, ini terlihat pada saat peserta didik diberi sebuah masalah, peserta didik belum bisa menyelesaikan permasalahan tersebut dan tidak mau mencoba mencari tahu jawabannya sendiri dari permasalahan yang diberikan. Peserta didik juga kurang memahami konsep fisika dengan cepat, karena pendidik menggunakan metode ceramah saat mengajar di kelas. Data dibuktikan hasil dari observasi yang dilakukan pada peserta didik.

Hasil observasi juga menunjukkan bahwa pendidik tidak pernah merancang sebuah bahan ajar yang berupa modul dan tidak pernah menerapkan modul saat mengajar di kelas. Data ini dibuktikan pada hasil dari observasi kepada pendidik mata pelajaran fisika yang dilampirkan pada halaman lampiran. Kegiatan pembelajaran di kelas pada mata pelajaran fisika hanya memakai buku ajar yang telah disediakan di perpustakaan sekolah. Pada saat proses pembelajaran berlangsung, peserta didik diberiberikan buku ajar oleh pendidik satu untuk berdua. Jadi, peserta didik belum bisa menggunakan buku ajar secara mandiri dan tidak diperbolehkan untuk dibawa pulang, karena setelah pembelajaran selesai buku ajar dikumpulkan kembali kepada pendidik. Buku ajar juga bisa dipinjam dari perpustakaan tetapi peserta didik juga tidak bisa menggunakan secara mandiri, karena satu buku ajar yang dipinjam untuk dua orang peserta didik dan peserta didik menggunakan bahan ajar tersebut dengan bergantian. Ini mengakibatkan ketergantungan peserta didik terhadap pendidik, ketika pendidik tidak masuk mengajar maka kegiatan pembelajaran tidak berjalan. Dalam kegiatan pembelajaran yang berpusat pada pendidik menghasilkan pemahaman peserta didik yang berbeda-beda. Ada peserta didik yang mudah dalam memahami pembelajaran dan ada juga peserta didik yang sulit memahami pembelajaran.

Dalam proses pembelajaran peserta didik juga cenderung bersikap pasif, sedangkan pendidik cenderung mendominasi. Akibatnya peserta didik ketergantungan, kurang inisiatif, tidak dilatih untuk belajar berdiskusi dan mandiri.
Uraian permasalahan di atas, maka perlu dibuatkan suatu sumber belajar yang dapat memfasilitasi peserta didik untuk belajar mandiri, salah satunya adalah modul pembelajaran berbasis Problem Solving. Problem Solving dapat membantu peserta didik dapat menyelesaikan suatu permasalahan saat belajar dengan sendiri, jadi, modul ini merupakan salah satu sumber belajar yang sangat efektif diterapkan untuk memahami materi pembelajaran dan melatih peserta didik untuk menyelesaikan permasalahan yang diberikan oleh pendidik. Melalui pengembangan modul peserta didik dapat memahami materinya dengan belajar mandiri, dan mampu mengukur kemampuan dirinya, sehingga dapat meningkatkan hasil belajar. Diketahui bahwa modul sebagai bahan ajar di SMP Negeri 16 Kerinci belum pernah digunakan karena sudah ada buku paket.

Prastowo (2011:105) menyatakan bahwa "modul adalah satuan program pembelajaran terkecil yang dapat dipelajari oleh peserta didik secara perseorangan (self instructional), setelah peserta menyelesaikan satu satuan dalam modul, selanjutnya peserta didik dapat melangkah maju dan mempelajari satuan modul berikutnya.

Prastowo (2011:105) menyatakan bahwa "modul pembelajaran merupakan suatu paket bahan pembelajaran (learning materials) yang memuat deskripsi tentang tujuan pembelajaran, lembaran petunjuk pengajar atau instruktur yang menjelaskan cara mengajar yang efisien, bahan bacaan bagi peserta didik, lembaran kunci jawaban pada lembar kertas kerja peserta, dan alat-alat evaluasi pembelajaran".

Dari penjelasan di atas, dapat disimpulkan bahwa modul adalah sebuah sumber belajar yang bisa membantu peserta didik untuk belajar mandiri dimanapun peserta didik berada, di sekolah maupun di rumah. Dengan adanya modul pembelajaran peserta didik bisa mengulang kembali materi yang belum dipahami saat belajar di sekolah. Peserta didik juga bisa mengukur kepahaman terhadap materi yang sudah dipelajari dengan mencoba menjawab soal-soal yang ada dalam modul tersebut.

Janawi (2013:213) menyatakan bahwa "Problem Solving (pemecahan masalah) merupakan model pembelajaran dimana peserta didik dihadapkan pada suatu kondisi bermasalah. Untuk itu anak didik harus menemukan sejumlah strategi untuk dapat 
memecahkan masalah tersebut". Berdasarkan hasil penelitian Lia Artika (2019) modul pembelajaran berbasis problem solving mampu membantu peserta didik memecahkan permasalahan dalam proses belajar secara mandiri, dan modul tersebut layak digunakan sebagai sumber belajar di sekolah.

Majid (2013:212) menyatakan bahwa "Problem Solving (pemecahan masalah) bukan hanya sekadar metode mengajar tetapi juga merupakan suatu metode berpikir karena dalam Problem Solving dapat menggunakan metodemetode lainnya yang dimulai dengan mencari data sampai pada menarik kesimpulan".

Kesimpulkan bahwa model Problem Solving merupakan model pembelajaran yang terdapat suatu permasalah yang harus diselesaikan oleh peserta didik serta dapat melatih peserta didik mendapatkan informasi dari sumber lain dan dapat berfikir kritis. Dengan mengembangkan modul pembelajaran berbasis Problem Solving ini peserta didik diharapkan lebih bisa mengerti bagaimana cara menyelesaikan suatu permasalahan dalam proses pembelajaran serta permasalahan yang dihadapinya dalam kehidupan nyata atau di luar lingkungan sekolah.

\section{METODE PENELITIAN}

Jenis penelitian yang digunakan penelitian pengembangan Research and Development (R\&D) dengan memakai model 4-D (four $D$ model). Trianto (2010:189) menyatakan bahwa "tahap-tahap itu adalah define (pendefinisian), yaitu tahapan yang bertujuan untuk menentukan dan mendefinisikan kebutuhan pembelajaran, tahap design (perancanaan), yaitu perencanaan prototipe perangkat pembelajaran, tahap develop (pengembangan), yaitu yang bertujuan untuk menghasilkan perangkat pembelajaran, tahap disseminate (penyebaran), yaitu tahap penggunaan perangkat yang dikembangkan". Dalam proses pelaksanaan tahap awal yaitu dengan membuat gambaran awal dari sebuah modul pembelajaran yang akan dikembangkan lalu dilaksanakan uji validasi oleh validator modul dan apabila ada saran maupun komentar dari validator dilakukan kegiatan revisi produk. Modul yang sudah valid diujicobakan di sekolah untuk melakukan uji praktikalitas terhadap modul yang dikembangkan. Selanjutnya karena keterbatasan waktu dan biaya tahap disseminate (penyebaran) tidak dilaksanakan.

\section{Instrumen Penelitian}

Instrumen yang digunakan pada penelitian berupa angket validitas dan angket praktikalitas:

\section{Instrumen Validasi}

Instrumen validasi digunakan untuk melihat kevalidan sebuah modul, yaitu berupa angket validasi yang terdapat beberapa aspek penilaian yaitu aspek materi modul, aspek penyajian madul dan aspek bahasa dan keterbacaan modul. Angket validitas modul diisi oleh dosen pendidikan fisika dan pendidik fisika SMP Negeri 16 Kerinci. Menurut Riduwan (2010:87) "angket disusun berdasarkan skala Likert dengan alternatif jawaban SS (sangat setuju), S (setuju), N (netral), TS (tidak setuju), STS (sangat tidak setuju)".

\section{Instrumen Praktikalitas}

Instrumen praktikalitas dipakai untuk melihat praktikalitas modul berupa angket praktikalitas yang terdiri dari beberapa aspek peniliaian yaitu aspek kemudahan dalam pengguna, waktu, manfaat, dan bahan ajar baru atau variasi. Angket praktikalitas disebarkan kepada pendidik fisika dan peserta didik setelah memakai modul pembelajaran fisika berbasis Problem Solving. Menurut Riduwan (2010:87) "angket disusun berdasarkan skala Likert dengan alternatif jawaban sangat setuju (SS), setuju (S), netral (N), tidak setuju (TS), sangat tidak setuju (STS)".

\section{Teknik Analisis Data}

Dalam penelitian ini teknik menganalisis data dilakukan dengan menggunakan analisis deskriptif yang terdiri dari dua analisis yaitu:

\section{Analisis Validitas}

Tahap-tahap untuk menganalisis validitas yaitu sebagai berikut:

a. Untuk masing-masing per item penskorannya dipakai skala likert dari skor 1-5 dengan ketentuan:

Tabel 1. Pernyataan Untuk Lembar Validitas Modul

\begin{tabular}{cr}
\hline Pernyataan Postif & Bobot \\
\hline Sangat Tidak Setuju & 1 \\
Tidak Setuju & 2 \\
Netral & 3 \\
Setuju & 4 \\
Sangat Setuju & 5 \\
\hline
\end{tabular}

Sumber: Riduwan (2010:87) 
b. Menjumlahkan skor tiap validator untuk seluruh indikator

c. Untuk mendapatkan nilai validasi dengan cara:

$$
\begin{aligned}
& \boldsymbol{N A}=\frac{\boldsymbol{S}}{\boldsymbol{S M}} \times \mathbf{1 0 0} \% \\
& \text { Dimana: } \text { NA }=\text { Nilai Akhir } \\
& \mathrm{S}=\text { Jumlah Semua Skor } \\
& \mathrm{SM}=\text { Skor Maksimum }
\end{aligned}
$$

Kategori validasi modul pembelajaran berdasarkan nilai akhir yang didapatkan, modul dapat dikatakan valid apabila persentasenya mencapai $>60$.

Tabel 2. Interpretasi Angket Validasi

\begin{tabular}{cc}
\hline Persentase & Kriteria \\
\hline $0-20 \%$ & Tidak valid \\
$21-40 \%$ & Kurang valid \\
$41-60 \%$ & Cukup valid \\
$61-80 \%$ & Valid \\
$81-100 \%$ & Sangat valid \\
\hline
\end{tabular}

Sumber: Riduwan (2010:89)

\section{Analisis Praktikalitas}

Angket praktikalitas peserta didik dan pendidik berkaitan dengan kepraktisan keterpakaian modul yang telah dibuat. Analisis praktikalitas dilakukan dengan menggunakan skala likert dengan ketentuan:

Tabel 3. Pernyataan Untuk Lembar Pratikalitas Modul

\begin{tabular}{cc}
\hline Pernyataan Postif & Bobot \\
\hline Sangat Tidak Setuju & 1 \\
Tidak Setuju & 2 \\
Netral & 3 \\
Setuju & 4 \\
Sangat Setuju & 5
\end{tabular}

Sumber: Riduwan (2010:87)

Untuk mendapatkan hasil akhir dari angket praktikalitas dianalisis dalam skala (0100) dengan menggunakan rumus:

$$
\mathbf{N P}=\frac{\text { Jumlah skor yang diperoleh }}{\text { Jumlah skor maksimum }} \times 100 \%
$$

Berdasarkan nilai akhir yang didapatkan, kategori praktikalitas modul pembelajaran dapat dikatakan praktis apabila persentasenya mencapai $>60$.
Tabel 4. Interpretasi Angket Praktikalitas

\begin{tabular}{cc}
\hline Persentase & Kriteria \\
\hline $0-20 \%$ & Tidak valid \\
$21-40 \%$ & Kurang valid \\
$41-60 \%$ & Cukup valid \\
$61-80 \%$ & Valid \\
$81-100 \%$ & Sangat valid \\
\hline
\end{tabular}

\section{HASIL DAN PEMBAHASAN}

Penelitian ini termasuk penelitian pengembangan yaitu penelitian yang berorientasi pada produk. Penelitian ini menggunakan model pengembangan 4-D (four $D$ model). dengan pembahasan tahapan-tahapan sebagai berikut:

\section{Tahap Pendefinisian (Define)}

Tahap pendefinisian ini dilakukan suatu analisis kebutuhan berupa analisis silabus, analisis buku teks, review literatur, wawancara untuk mengetahui bagaimana keadaan kejadian di lapangan. Sehingga dilakukan analisis kebutuhan modul fisika yang akan dikembangkan. Diantaranya analisis silabus, analisis buku teks, dan interview terhadap pendidik dan peserta didik untuk menganalisis karakteristik peserta didik. Langkah kegiatan yang dilaksanakan untuk analisis tersebut yaitu:

\section{a. Analisis Silabus}

Adapun hasil analisis silabus yaitu, silabus telah memiliki ketetapan $\mathrm{KI} / \mathrm{KD}$ yang telah sesuai dengan standar isi dan karakteristik pembelajaran. Berdasarkan isi silabus materi gerak dan gaya terdapat dalam materi pokok ke1 pada semester 1 . Materi gerak dan gaya ini terdiri dari beberapa bahasan dengan waktu pelajaran sebanyak 5 jam pelajaran.

Kompetensi dasar yang terdapat pada materi gerak dan gaya adalah KD 3.1 Memahami gerak lurus, dan pengaruh gaya terhadap gerak berdasarkan hukum newton, serta penerapan pada gerak makhluk hidup dan gerak benda dalam kehidupan sehari-hari.

\section{b. Analisis Buku Teks}

Buku teks yang diamati yaitu buku Ilmu Pengetahuan Alam dari Kemendikbud untuk peserta didik kelas VIII SMP. Analisis buku teks bertujuan untuk melihat kesesuaian materi terhadap kompetensi dasar yang ada pada silabus. Di dalam buku teks yang dipakai oleh peserta didik belajar di kelas sudah berkaitan dengan KD yang akan dicapai. Tetapi dalam penyajian buku teks belum mengarahkan peserta didik untuk menemukan suatu konsep dari suatu 
materi. Buku teks juga belum menampilkan kriteria penilaian autentik.

Berdasarkan analisis yang dilakukan pada buku pegangan peserta didik terlihat bahwa urutan sub topik dan materi sudah sesuai dengan KD yang dicapai, pada pendahuluan bab memotivasi peserta didik untuk belajar, cakupan pada materi gerak dan gaya sudah bagus dalam penyajian materinya dan dilengkapi dengan penilaian proses dan hasil belajar, tetapi pada buku teks yang dipakai peserta didik belum dilengkapi kriteria penilaian.

\section{c. Review Literatur}

Buku-buku yang direview adalah bukubuku yang berhubungan dengan gerak dan gaya. Materi gerak dan gaya diambil dari buku terbitan Erlangga, buku dari Kemendikbud serta buku-buku pengayaan lainnya. Sedangkan buku panduan kreatif membuat bahan ajar inovatif adalah buku karangan Prastowo (2011). Buku Sani (2019) memuat sintaks-sintaks Problem Solving yang dijadikan acuan oleh peneliti dalam mengembangkan modul berbasis Problem Solving.

\section{d. Wawancara dengan pendidik dan peserta didik}

Hasil wawancara menunjukkan, bahwa kegiatan pembelajaran fisika hanya menggunakan satu buku panduan saja. Peserta didik hanya bergantung terhadap penjelasan pendidik untuk memahami dan mendapatkan materi pelajaran. Oleh karena itu, peserta didik dikatakan belum bisa belajar secara mandiri, maka diperlukan suatu sumber belajar yang praktis dari pendidik sehingga mampu memfasilitas peserta didik untuk belajar secara sendiri berupa modul. Dengan menggunakan modul peserta didik mendapatkan tambahan sumber belajar serta memfasilitasi peserta didik untuk menunjang aktivitas peserta didik dalam belajar.

\section{Tahap Perancangan (Design )}

Hasil dari tahap design ini dipakai sebagai dasar pada tahap perancangan modul pada materi gerak dan gaya. Berikut merupakan tampilan struktur isi modul berbasis Problem Solving yang telah dinyatakan sangat valid oleh validator.

\section{a. Cover Modul}

Cover modul dibuat semenarik mungkin menggunakan warna-warna cerah. Cover didesain dengan menggunakan kombinasi warna biru muda, pink dan abu-abu. Modul yang dirancang terdapat judul modul fisika pada materi gerak dan gaya peserta kelas VIII SMP, dan di cover terdapat nama dan kelas peserta didik.

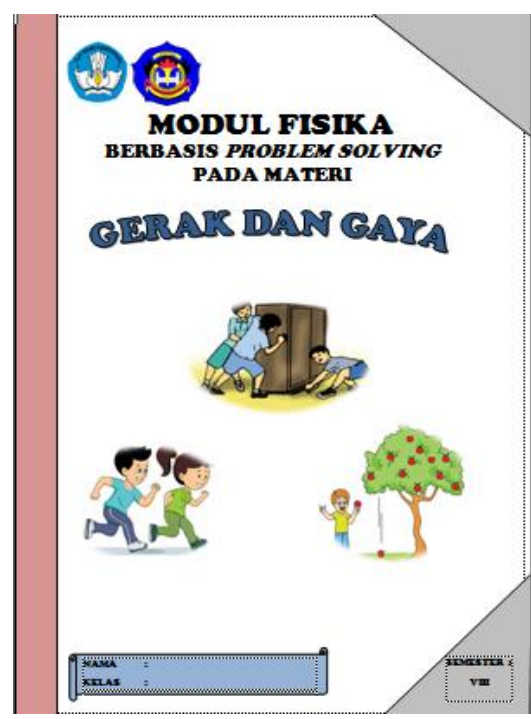

Gambar 1. Cover Modul

\section{b. Kata pengantar}

Modul yang dikembangkan terdapat kata pengantar yaitu ungkapan rasa syukur terhadap Tuhan yang Maha Esa, dan ucapan terima kasih penulis terhadap pihak yang telah membantu dalam proses penyusunan modul pembelajaran fisika untuk peserta didik kelas VIII SMP.

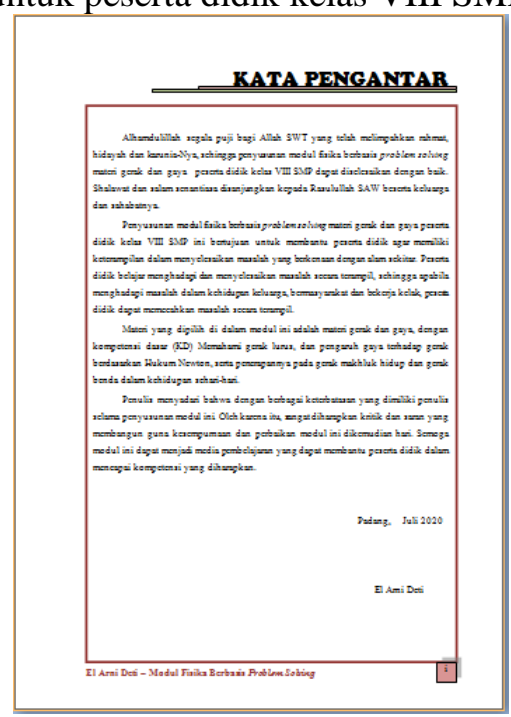

Gambar 2. Kata Pengantar

\section{c. Daftar isi}

Daftar isi ini merupakan panduan bagi peserta didik dan pendidik untuk cepat mengakses materi atau bahan yang akan dicari di dalam modul tersebut. 


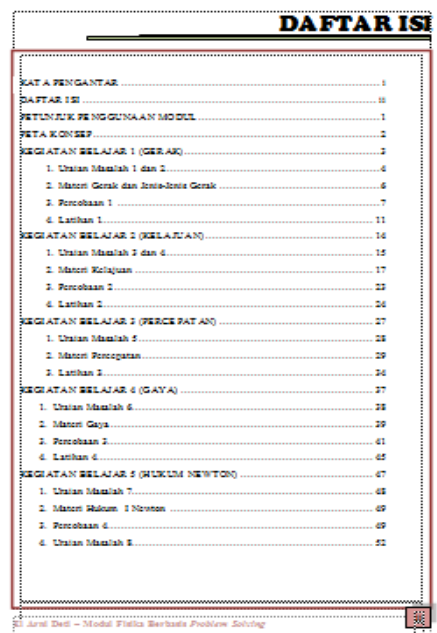

Gambar 3. Daftar Isi

\section{d. Petunjuk Penggunaan Modul}

Pada petunjuk penggunaan modul fisika berbasis Problem Solving ini berisi tentang langkah-langkah cara penggunaan modul. Pada petunjuk penggunaan modul ini terdapat petunjuk bagi peserta didik dan pendidik.

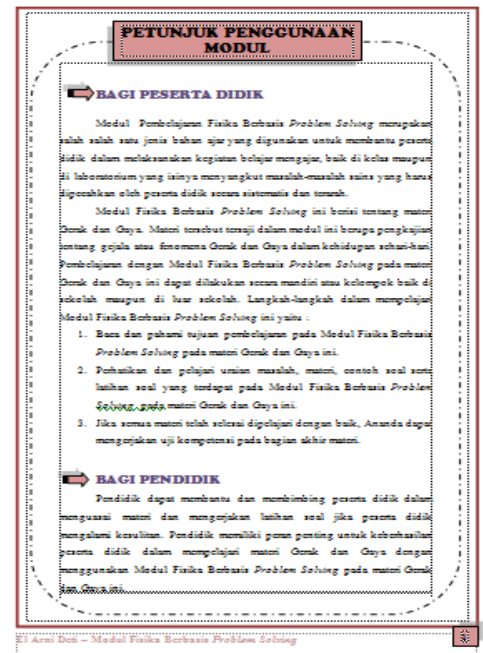

Gambar 4. Petunjuk penggunaan modul

\section{e. Peta Konsep}

Pada modul pembelajaran berbasis Problem Solving ini terdapat peta konsep yang berisi tentang gambaran garis besar konsep-konsep materi yang terdapat pada isi modul.

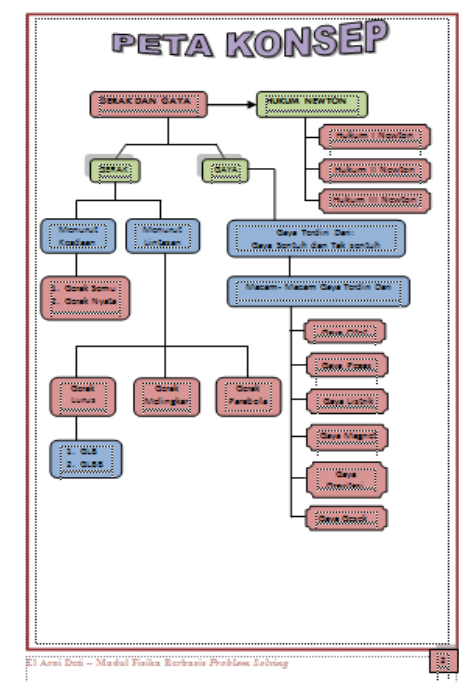

Gambar 5. Peta Konsep

\section{f. Kegiatan Belajar}

Adapun pada kegiatan belajar terdapat 5 kegiatan pembelajaran. Dimana dalam susunan kegiatan pembelajarab terdapat sintak-sintak dari model pembelajaran Problem Solving. Berikut ini merupakan tampilan isi modul berbasis Problem Solving:

\section{1) Menyajikan Permasalahan}

Pada penyajian masalah ini bertujuan memusatkan perhatian peserta didik agar dapat menemukan permasalahan dan konsep yang berhubungan tentang materi yang akan dipelajari.

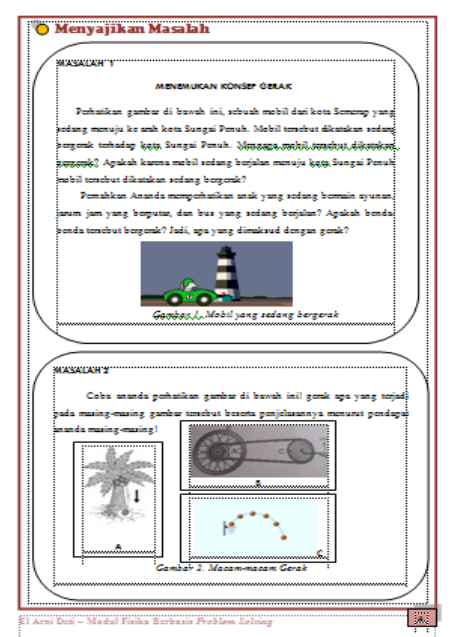

\section{Gambar 6. Penyajian Masalah}

\section{2) Mengidentifikasi Permasalah}

Peserta didik diminta untuk merumuskan masalah dan menjelaskan pendapat mereka sendiri dari masalah yang diberikan. Peserta 
didik menjelaskan pendapat mereka di tempat yang sudah disediakan berupa kolom.

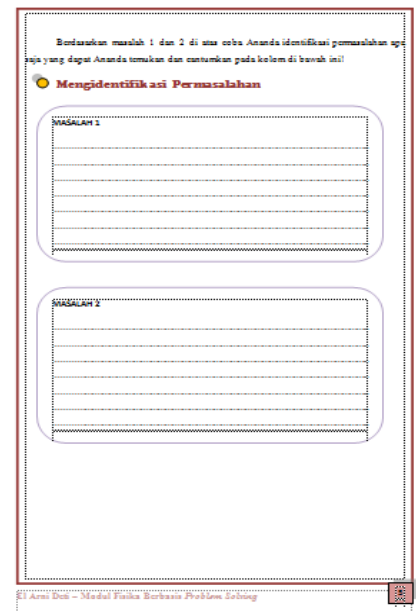

Gambar 7. Mengidentifikasi Permasalah

\section{3) Mencari Alternatif Penyelesaian Masalah}

Pada pencarian alternatif penyelesaian masalah ini terdapat materi dan jawaban tentang masalah yang disajikan, yang dapat digunakan oleh peserta didik untuk mendapatkan informasi lebih luas tentang konsep masalah yang terkait pada materi belajar.

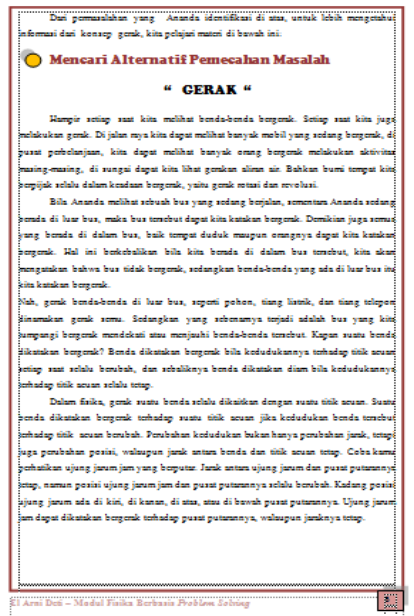

Gambar 8. Alternatif Penyelesaian Masalah

\section{4) Menilai Setiap Alternatif Penyelesaian Masalah}

Pada langkah ini peserta didik melakukan evaluasi berupa latihan yang akan dinilai oleh pendidik, dengan tujuan untuk melihat sejauh mana pemahaman peserta didik terhadap materi yang dipelajari sebelumnya.

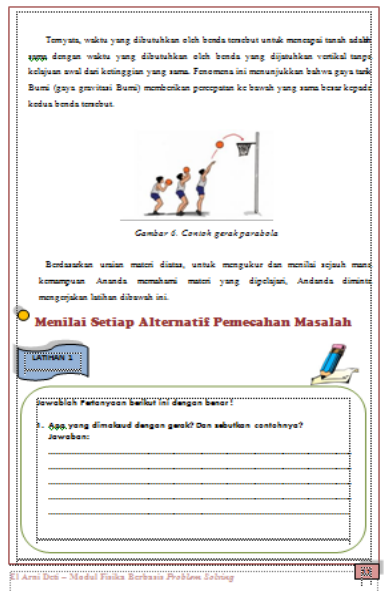

\section{Gambar 9. Menilai Alternatif Pemecahan Masalah}

\section{5) Menarik Kesimpulan}

Peserta didik diminta untuk membuat kesimpulan terhadap materi yang sudah dipelajari sebelumnya yang terdapat pada kolom yang telah disediakan.

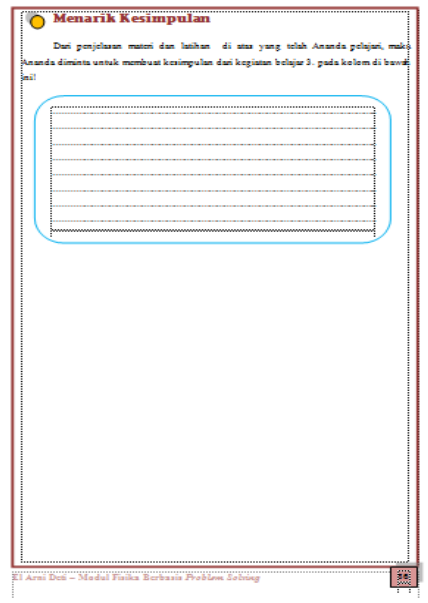

\section{Gambar 10. Menarik Kesimpulan}

\section{g) Uji Kompetensi}

Pada Modul fisika berbasis Problem Solving ini terdapat uji kompetensi untuk peserta didik. Dengan adanya uji kompetensi ini peserta didik bisa mengukur dan melihat sejauh mana penguasaan materi oleh peserta didik pada kegiatan 1 sampai 5 yang telah dilakukan. Uji Kompetensi terdapat soal pilihan ganda dan isian. 


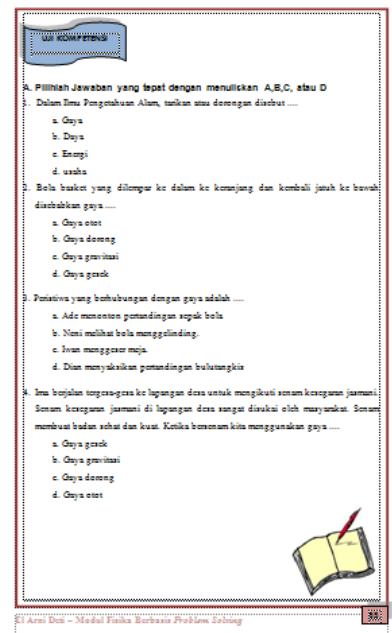

Gambar 11. Uji Kompetensi

\section{h) Kriteria Penilaian}

Penilaian diberikan kepada peserta didik selesai mengerjakan latihan yang terdapat pada modul. Penilian ditampilkan dalam sebuah kotak.

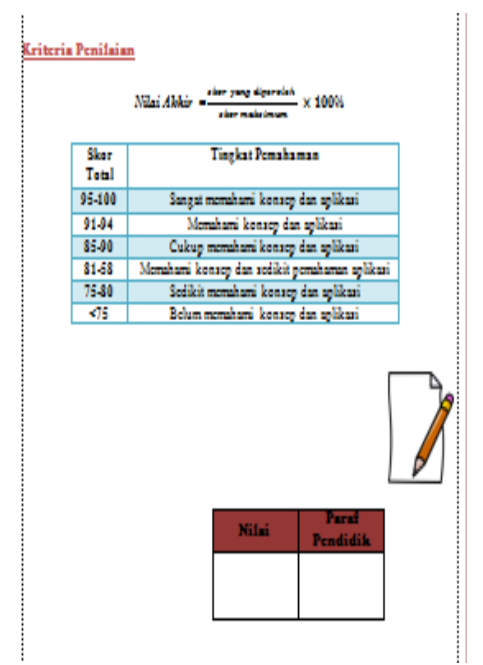

Gambar 12. Penilaian

\section{i) Daftar Pustaka}

Pada modul fisika yang dikembangkan terdapat daftar pustaka yang berisi tentang rujukan atau sumber referensi yang dipakai dalam penyusunan modul.

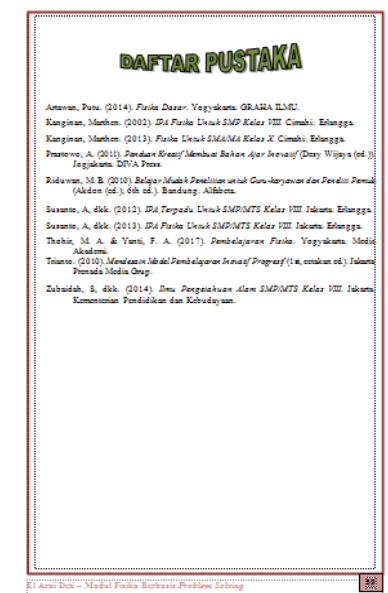

\section{Gambar 13. Daftar Pustaka}

\section{Tahap Pengembangan (Development)}

Tahap pengembangan yaitu mendapatkan hasil modul berbasis Problem Solving terhadap materi gerak dan gaya peserta didik kelas VIII SMP Negeri 16 Kerinci yang valid dan praktis. Tahap ini memiliki dua tahap yang harus dilakukan yaitu tahap validasi produk serta tahap praktikalitas.

\section{a. Tahap Validasi Produk}

Tahap ini modul yang telah dirancang selanjutnya divalidasi oleh validator. Modul divalidasi oleh 2 validator, yaitu dua orang dosen pendidikan fisika dari STKIP PGRI Sumatera Barat. Tujuan dilakukannya validasi adalah agar dapat dikatakan sebagai modul yang valid dan dapat dipertanggung jawabkan. Kegiatan validasi modul diawali dengan pengamatan terhadap modul oleh validator, kemudian pengisian angket oleh validator sebagai data hasil validasi. Modul ini telah dirancang dan divalidasi dari segi materi, penyajian dan bahasa. Hasil validasi menunjukkan bahwa modul sudah sangat valid. Modul pembelajaran fisika berbasis Problem Solving telah divalidasi oleh 2 orang validator yaitu 2 orang Dosen Program Studi Fisika. Berdasarkan hasil validasi menunjukkan bahwa isi dari modul yang dikembangkan yaitu: cara penggunaan modul, KD, indikator pencapaian, tujuan yang harus dicapai dalam pembelajaran, uraian masalah, uraian materi, soal latihan, dan penilaian. Nilai rata-rata keseluruhan dari validator didapatkan nilai 97,03\% dikategorikan sangat valid. 
Tabel 5. Hasil Validasi Seluruh Aspek pada Modul

\begin{tabular}{|c|c|c|c|c|c|}
\hline \multirow{2}{*}{ No } & \multirow{2}{*}{$\begin{array}{c}\text { Aspek } \\
\text { Validasi }\end{array}$} & \multicolumn{2}{|c|}{ Validator } & \multirow{2}{*}{$\begin{array}{c}\text { Rata- } \\
\text { Rata } \\
\text { Validasi }\end{array}$} & \multirow{2}{*}{ Kategor } \\
\hline & & $\mathbf{I}$ & II & & \\
\hline 1 & $\begin{array}{l}\text { Aspek } \\
\text { Materi dari } \\
\text { modul }\end{array}$ & $\begin{array}{c}93,33 \\
\%\end{array}$ & $\begin{array}{c}97,78 \\
\%\end{array}$ & $95,55 \%$ & $\begin{array}{l}\text { Sangat } \\
\text { Valid }\end{array}$ \\
\hline 2 & $\begin{array}{l}\text { Aspek } \\
\text { penyajian } \\
\text { modul }\end{array}$ & $\begin{array}{c}94,55 \\
\%\end{array}$ & $\begin{array}{c}96,36 \\
\%\end{array}$ & $95,46 \%$ & $\begin{array}{l}\text { Sangat } \\
\text { Valid }\end{array}$ \\
\hline 3 & $\begin{array}{l}\text { Aspek } \\
\text { bahasa dan } \\
\text { keterbacaan } \\
\text { pada modul }\end{array}$ & $100 \%$ & $100 \%$ & $100 \%$ & $\begin{array}{l}\text { Sangat } \\
\text { Valid }\end{array}$ \\
\hline \multicolumn{4}{|c|}{ Nilai Rata-rata Keseluruhan } & $97,03 \%$ & $\begin{array}{c}\text { Sangat } \\
\text { Valid }\end{array}$ \\
\hline
\end{tabular}

Berdasarkan Tabel 5 didapatkan nilai rata-rata dari keseluruhan aspek validasi modul dari ketiga validator adalah 97,03\% dikategorikan sangat valid.

\section{b. Tahap Praktikalitas}

Tahap praktikalitas dilaksanakan di sekolah pada tanggal 20 Juli - 19 Agustus 2020. Pelaksanaan praktikalitas dilakukan saat jam pelajaran fisika di kelas VIII B SMP Negeri 16 Kerinci. Pada tahap praktikalitas ini peneliti melibatkan 1 orang pendidik fisika dan 24 orang peserta didik. Kepraktisan mengacu pada kemudahan dalam penggunaan media yang dikembangkan. Pada uji praktikalitas ini merupakan penyebaran angket praktikalitas modul untuk mengetahui respon dari pengguna media yaitu peserta didik dan pendidik terhadap modul yang dikembangkan. Responden dalam uji praktikalitas adalah 24 orang peserta didik kelas VIII B dan 1 pendidik yang mengajar fisika di SMP Negeri 16 Kerinci.

Dari hasil rata-rata keseluruhan nilai kepraktikalitas terhadap peserta didik dan pendidik diperoleh nilai 91,63\% dikategorikan sangat praktis. Berdasarkan hasil dari angket validasi dan praktikalitas modul, kesimpulan yang dapat diambil yaitu modul pembelajaran berbasis Problem Solving untuk peserta didik kelas VIII SMP Negeri 16 Kerinci pada materi gerak dan gaya dikategorikan sangat valid dan sangat praktis. Berikut merupakan hasil dari praktikalitas terhadap pendidik dan peserta didik.
Tabel 6. Hasil Praktikalitas Pendidik Dan Peserta Didik

\begin{tabular}{c|c|c|c}
\hline No & Responden & $\begin{array}{c}\text { Nilai } \\
\text { Praktikalitas }\end{array}$ & Kategori \\
\hline 1 & Pendidik & $90,79 \%$ & $\begin{array}{l}\text { Sangat } \\
\text { Praktis }\end{array}$ \\
\hline 2 & Peserta Didik & $92,48 \%$ & $\begin{array}{l}\text { Sangat } \\
\text { Praktis }\end{array}$ \\
\hline $\begin{array}{c}\text { Rata-Rata } \\
\text { Keseluruhan Nilai } \\
\text { Kepraktikalitas }\end{array}$ & $\mathbf{9 1 , 6 3 \%}$ & $\begin{array}{c}\text { Sangat } \\
\text { Praktis }\end{array}$ \\
\hline
\end{tabular}

Berdasarkan Tabel 6 di atas persentase yang diperoleh dari hasil praktikalitas pada modul terhadap pendidik dan peserta didik didapatkan nilai rata-rata adalah 91,63\% dikategorikan sangat praktis.

\section{PEMBAHASAN}

Berdasarkan penjelasan di atas yang sudah dijelaskan kesimpulan yang dapat diambil yaitu validitas dan praktikalitas menentukan baik atau tidaknya kualitas suatu produk yang dikembangkan agar dapat digunakan lebih luas lagi atau sampai tahap penyebaran. Wenno (2010:179) menyatakan bahwa "dalam memilih media yang baik dan berkualitas media tersebut harus divalidkan oleh ahli yang telah teruji, dimana media yang dibuat mampu menyampaikan suatu konsep atau materi yang akan dipelajari".

Sejalan dengan hal tersebut Rochmad (2012:13) mengungkapkan bahwa "suatu hasil pengembangan (produk) dikatakan valid jika produk berdasarkan teori yang memadai (validitas isi) dan semua komponen produk pembelajaran satu sama lain berhubungan secara konsisten (validitas konstruk)".

Gusnedi (2018:153) menyatakan bahwa "validitas bahan ajar ditentukan untuk mengetahui kualitas bahan ajar dalam kaitannya dengan mengukur hal yang seharusnya diukur". Hasil dari uji validitas menunjukkan bahwa secara umum dapat dikatakan bahwa bahan ajar valid untuk digunakan.

Selain kevalidan, kelayakan sebuah produk juga ditentukan oleh praktikalitas produk tersebut. Gusnedi (2018:157) menyatakan bahwa "praktikalitas adalah tingkat keterpakaian dan keterlaksanaan bahan ajar oleh siswa dan guru yaitu melaksanakan pembelajaran dengan menggunakan bahan ajar yang telah direvisi berdasarkan penilaian validator". Berdasarkan penjelasan di atas yang sudah dijelaskan 
kesimpulan yang dapat diambil yaitu jika sebuah produk berupa bahan ajar telah dikatakan valid dan praktis termasuk dalam kategori baik bagi validator, jadi bahan ajar tersebut dinyatakan layak untuk diterapkan di lapangan.

\section{KESIMPULAN}

Pengembangan modul pembelajaran fisika berbasis Problem Solving untuk peserta didik kelas VIII SMP Negeri 16 Kerinci terkategori valid dan praktis. Adapun hasil validasi modul pembelajaran dari 2 orang validator diperoleh nilai rata-rata validasi adalah $97,03 \%$ yang dikategorikan sangat valid.

Sedangkan hasil praktikalitas modul terhadap pendidik dan peserta didik didapatkan nilai rata-rata praktikalitas adalah $91,63 \%$ dikategorikan sangat praktis. Artinya modul yang sudah dikembangkan praktis digunakan oleh peserta didik di SMP Negeri 16 Kerinci.

\section{DAFTAR PUSTAKA}

Arikunto, Suharsimi. (2018). Dasar-Dasar Evaluasi Pendidikan. Jakarta: Bumi Aksara

Artika, Lia. (2019). Pengembangan Modul Biologi Berbasis Problem Solving Pada Materi Ekosistem Untuk Siswa Kelas X SMA.Lampung.

Gusnedi. (2018). Analisis Validitas, Praktikalitas, Dan Efektivitas Pengembangan Bahan Ajar Terintegrasi Konten Kecerdasan Spiritual Pada Materi Fisika Tentang Vektor Dan Gerak Lurus. Jurnal. Pillar of Physics Education, Vol 11. No 2, Oktober 2018, 153-160.

Janawi. (2013). Metodologi dan Pendekatan Pembelajaran (Nor Huda (ed.)). Yogyakarta: Penerbit Ombak.

Khuluqo, I. El. (2017). Belajar dan Pembelajaran Konsep Dasar, Metode dan Aplikasi Nilai-Nilai Spiritualitas Dalam Proses Pembelajaran (Abi Fairuz Ulil Albab (ed.); 1 st ed.). Yogyakarta: PUSTAKA PELAJAR.

Majid, Abdul. (2013). Strategi Pembelajaran (Engkus Kuswandi (ed.)). Bandung: PT. REMAJA ROSDAKARYA.

Prastowo, A. (2011). Panduan Kreatif Membuat
Bahan Ajar Inovatif (Desy Wijaya (ed.)). Jogjakarta: DIVA Press.

Riduwan, M. B. (2010). Belajar Mudah Penelitian untuk Guru-karyawan dan Peneliti Pemula (Akdon (ed.); 6th ed.). Bandung: Alfabeta.

Rochmad. (2011). Desain Model Pengembangan Perangkat Pembelajaran. Jurnal Kreano.

Rusman. (2012). Model-Model Pembelajaran Mengembang Profesionalisme Guru (2nd ed.). Jakarta: PT. Raja Grafindo Persada.

Sani, R. A. (2019). Pembelajaran Berbasis HOTS (Higher Order Thinking Skills) (1st ed.). Tangerang: Tsmart Printing.

Shoimin, A. (2016). 68 Model Pembelajaran Inovatif Dalam Kurikulum 2013 (Rose KR (ed.)). Yogyakarta: AR-RUZZ MEDIA.

Suardi, M. S, dkk. (2018). Belajar dan Pembelajaran. Yogyakarta: Parama Ilmu.

Sukmadinata, prof. D. N. S. (2010). Metode Penelitian Pendidikan. Bandung: PT remaja rosdakarya.

Thohir, M. A. dkk. (2017). Pembelajaran Fisika Kesulitan Belajar dan Cara Mengatasinya (1st ed.). Yogyakarta: Media Akademi.

Trianto. (2010). Mendesain Model Pembelajaran Inovatif Progresif (1st, cetakan ed.). Jakarta: Prenada Media Grup.

Ulya, Haritsyah. (2017). Pengembangan Modul Kimia Yang Berbasis Problem Solving Pada Materi Asam Dan Basa Arrhenius. Lampung.

UU No. 20 Tahun 2003 Tentang Sistem Pendidikan

Nasional,(https://kelembagaan.ristekdikti.g o.id/wpcontent/uploads/2016/08/UU no 20 th_2003.pdf, diakses pada 29 januari 2020).

Wenno, I. H. (2010).Pengembangan Model Modul IPA Berbasis Problem Solving Method Berdasarkan Karakteristik Siswa Dalam Pembelajaran Di SMP/MTS. Jurnal cakrawala pendidikan, 2(2), 176-188. Https://Doi.Org/10.21831/Cp.V2i2.338 